\title{
Perbandingan Kadar Hemoglobin pada Bayi yang Diberikan Makanan Pendamping ASI Buatan Pabrik dengan Buatan Rumahan
}

\author{
Hani Hilda Kartika, Dida Akhmad Gurnida, Aris Primadi \\ Bagian Ilmu Kesehatan Anak Fakultas Kedokteran Universitas Padjadjaran, Rumah Sakit Dr. Hasan Sadikin, Bandung
}

Latar belakang. Anemia merupakan masalah kesehatan global di dunia. Penyebab tertinggi anemia adalah defisiensi besi, umumnya terjadi setelah usia 6 bulan saat masa penyapihan. Dinegara berkembang, orangtua lebih sering memberikan MPASI buatan rumahan yang seringkali tidak dapat memenuhi kebutuhan zat mikronutrien dibandingkan MPASI berfortifikasi buatan pabrik karena alasan ekonomi.

Tujuan. Mendapatkan gambaran perbedaan kadar Hemoglobin ( $\mathrm{Hb}$ ) bayi yang diberikan MPASI buatan pabrik dengan buatan rumahan.

Metode. Penelitian analitik komparatif potong lintang dilaksanakan pada Mei-Juni 2018 di wilayah kerja Puskesmas Garuda kota Bandung pada bayi usia 7-8 bulan secara consecutive sampling yang memenuhi kiteria inklusi untuk masing-masing kelompok MPASI buatan pabrik dan buatan rumahan. Dilakukan pengukuran kadar Hb dan recall pemberian makanan dalam 7 hari terakhir. Uji statistik dilakukan menggunakan uji t dan Mann Whitney dengan tingkat kemaknaan $\mathrm{p}<0,05$.

Hasil.Terdapat 36 bayi terbagi dalam 2 kelompok. Rerata kadar Hb bayi kelompok MPASI buatan pabrik 11,48 g/dL (0,85 SD), kelompok buatan rumahan 10,8 g/dL (1,2 SD). Didapatkan perbedaan yang bermakna antara jenis MPASI dengan kadar Hb (p<0.03). Kesimpulan.Kadar hemoglobin bayi yang mendapatkan MPASI buatan pabrik lebih tinggi dibandingkan bayi yang mendapatkan MPASI buatan rumahan. MPASI berfortifikasi buatan pabrik dapat diberikan sebagai salah satu upaya pencegahan anemia. Sari Pediatri 2019;20(5):276-82

Kata kunci: buatan pabrik, buatan rumahan, hemoglobin, MPASI, zat besi

\section{Comparison of Hemoglobin Levels in Infants Fed with Factory-made and Home-made Complementary Food}

Hani Hilda Kartika, Dida Akhmad Gurnida, Aris Primadi

Background. Anemia is a global health concern. Anemia, particularly caused by iron deficiency, occurs after 6 months of age at the time of weaning period. Considering economic reason, most infants in developing countries rarely given factory-made complementary food with higher iron content and given a home-made complementary food with traditional recipes, which frequently fail to fulfill the nutrition requirement.

Objective. To assess the difference in Hemoglobin ( $\mathrm{Hb}$ ) levels in infants fed with factory-made complementary food compared tohome-made complementary food.

Methods. A comparative analytic cross-sectional study conducted in May-June 2018 at Garuda, primary health service area in Bandung city. Infants age 7 to 8 month-old who fulfilled the inclusion criteria by consecutive sampling were classified into two groups: factory-made and home-made complementary food. Hb levels were measured. Seven days food recall was done by the enumerator. The statistical test was performed using t-test and Mann Whitney test with significance level of $p<0,05$.

Result. Thirty six infants were enrolled into the study, divided into 2 groups. The Hb average level in factory-made supplement was group $11.48 \mathrm{~g} / \mathrm{dL}(0.85 \mathrm{SD})$, compared to $10.82 \mathrm{~g} / \mathrm{dL}$ group $(1.20 \mathrm{SD})$. This difference was statistically $\operatorname{significant}(\mathrm{p}<0.03)$.

Conclusion. The average hemoglobin level in infants who were fed with factory-made food supplement at age 7-8 months was significantly higher compared to than home-made group. Fortified factory-made complementary food can be given as one of anemia prevention strategy. Sari Pediatri 2019;20(5):276-82

Keywords: complementary food, factory-made, home-made, hemoglobin, iron

Alamat korespondensi: Dida A Gurnida. Departemen Ilmu Kesehatan Anak Fakultas Kedokteran UNPAD Gedung Kenanga Lantai 3, Jl. Pasteur No.38, Bandung 40163. Email: didaag@yahoo.com 
A nemia merupakan masalah kesehatan global di dunia. Penyebab anemia di antaranya, defisiensi besi, infeksi, kelainan endokrin, perdarahan, dan penyakit kronis. ${ }^{1-3}$ Berdasarkan data kadar hemoglobin pada anak di negara industri dan non industri tahun 1991-1995, prevalensi anemia $60 \%$ dan $88,1 \%$. Negara di Asia Tenggara, jumlah kasus anemia anak usia $0-4$ tahun sebanyak 111.426. ${ }^{1}$ Kassebaum $^{3}$ melaporkan bahwa defisiensi besi merupakan penyebab anemia secara global pada tahun 1990-2010. Berdasarkan data Survey Kesehatan Rumah Tangga (SKRT) tahun 2004, anemia defisiensi besi (ADB) terjadi pada 31,4\% balita. ${ }^{4}$ Berdasarkan hasil Riset Kesehatan Dasar (Riskesdas) tahun 2013, anak usia 12 bulan hingga 14 tahun menduduki peringkat tertinggi untuk prevalensi terjadinya anemia, sebesar $54,5 \%$ dari total penduduk. ${ }^{2}$ Umumnya, ADB terjadi setelah bayi berusia 6 bulan saat masa penyapihan jika pemberian makanan pendamping tidak mengandung besi dan mikronutrien yang adekuat, sekalipun bayi mendapatkan ASI eksklusif. Hal tersebut dikarenakan pembentukan hemoglobin $(\mathrm{Hb})$ sangat dipengaruhi oleh besi, asam folat, vitamin B12, dan zinc. . $^{5-7}$

Makanan pendamping ASI (MPASI) adalah makanan atau minuman selain ASI yang mengandung zat gizi yang diberikan selama periode pemberian makanan peralihan (complementary feeding) dengan tujuan untuk memenuhi kebutuhan gizi, mengembangkan kemampuan bayi menerima berbagai macam makanan dengan berbagai rasa dan tekstur, mengembangkan kemampuan mengunyah dan menelan serta melakukan adaptasi terhadap makanan dengan kandungan energi tinggi. Pemberian MPASI mulai usia 6 bulan, dapat berupa buatan rumahan ataupun buatan pabrik dan harus memenuhi syarat, antara lain, tepat waktu, adekuat, aman, dan tepat cara pemberian. ${ }^{910}$ Di negara berkembang, MPASI berfortifikasi buatan pabrik dengan kadar besi lebih tinggi jarang diberikan karena pertimbangan ekonomis. Ibu lebih sering membuat MPASI buatan rumahan dengan resep tradisional dan seringkali zat gizi yang diberikan tidak seimbang dan tidak dapat memenuhi kebutuhan zat mikronutrien. ${ }^{9}$

Fortifikasi makanan dicanangkan oleh WHO pada tahun 1992 dan direkomendasikan bagi negara-negara yang berisiko tinggi terjadinya defisiensi zat besi. ${ }^{1}$ Di negara berkembang dengan keterbatasan sumber daya, indikator yang dianjurkan untuk diagnosis $\mathrm{ADB}$ adalah pemeriksaan $\mathrm{Hb}$ dan $\mathrm{Ht}$ sebagai langkah awal skrining dan konfirmasi diagnostik. Kriteria anemia pada anak jika didapatkan kadar $\mathrm{Hb}<11 \mathrm{~g} / \mathrm{dL}$ untuk usia 6-59 bulan. ${ }^{1}$ Penelitian Patron ${ }^{12}$ mengemukakan korelasi positif makanan pendamping berfortifikasi dengan kadar $\mathrm{Hb}$ anak usia 6-23 bulan. Penelitian lain menyebutkan bahwa kandungan mikronutrien makanan pendamping yang berasal dari tumbuhan dan tidak berfortifikasi tidak memadai kebutuhan harian. ${ }^{14}$ Penelitian ini bertujuan untuk mengetahui gambaran kadar Hb bayi yang diberikan MPASI buatan pabrik dibandingkan dengan buatan rumahan pada anak usia 7-8 bulan didaerah urban di Kota Bandung.

\section{Metode}

Rancangan penelitian ini adalah penelitian analitik komparatif dengan pendekatan potong lintang di wilayah kerja Puskesmas jejaring Fakultas Kedokteran Universitas Padjadjaran Bandung (Puskesmas Garuda) mulai bulan Mei-Juni 2018. Pemeriksaan darah dilakukan di laboratorium Prodia Bandung. Kriteria inklusi adalah bayi berusia 7-8 bulan, lahir cukup bulan berat lahir $>2500$ gram, dalam keadaan sehat, dan mendapat MPASI buatan rumahan atau pabrik. Kriteria eksklusi adalah bayi yang mendapat suplementasi besi, bayi yang mendapat vitamin yang mengandung besi, berat lahir $\geq 4000$ gram, orangtua menolak berpartisipasi. Subjek diambil dengan cara consecutive sampling hingga terpenuhi minimal 15 subjek untuk masing-masing kelompok.

Orangtua subjek penelitian yang telah bersedia bayinya diikutsertakan dalam penelitian menandatangani surat persetujuan. Pada subjek penelitian dilakukan pengambilan sampel darah 2-3 $\mathrm{mL}$ dari vena perifer kemudian sampel dikirim ke laboratorium Patologi Klinik PRODIA Bandung untuk pemeriksaan kadar $\mathrm{Hb}$ serum menggunakan metode sysmex. Penelitian ini telah memperoleh kelaikan etik dari Komite Etik Fakultas Kedokteran Universitas Padjadjaran, Bandung.

Dilakukan pengambilan data yang meliputi usia, jenis kelamin, berat badan lahir, paritas, pekerjaan dan pendidikan ibu, umur kehamilan, pemberian ASI, jenis makanan yang diberikan dan recall pemberian makan dalam 24 jam dan dalam 7 hari terakhir oleh seorang enumerator. Analisis statistik dilakukan sesuai tujuan penelitian dan hipotesis. Uji kemaknaan 
untuk membandingkan karakteristik dua kelompok penelitian digunakan uji t tidak berpasangan jika data berdistribusi normal dan uji Mann Whitney sebagai alternatifnya jika data tidak berdistribusi normal. Data yang diperoleh dicatat dalam formulir khusus kemudian diolah melalui program SPSS versi 15.0 for Windows 24.0. Tingkat kemaknaan dalam penelitian ini dinyatakan bila $\mathrm{p}<0,05$.

\section{Hasil}

Didapatkan 36 subjek penelitian yang terbagi menjadi dua kelompok, masing-masing 18 bayi pada kelompok yang diberikan MPASI buatan pabrik maupun rumahan. Karakteristik umum subjek penelitian mencakup jenis kelamin, pekerjaan, tingkat pendidikan ibu, cara lahir, paritas, penolong persalinan, status gizi dan pemberian ASI eksklusif tertera pada Tabel 1.

Pada Tabel 1 tertera bahwa dari 2 kelompok subjek, jenis kelamin perempuan $(\mathrm{n}=13)$ lebih banyak dibandingkan jenis kelamin laki-laki $(\mathrm{n}=5)$ pada kelompok MPASI buatan pabrik, sedangkan pada kelompok buatan rumahan jenis kelamin laki-laki $(\mathrm{n}=11)$ lebih banyak dibandingkan perempuan $(\mathrm{n}=7)$. Tujuhpuluh lima persen dari kedua kelompok $(\mathrm{n}=27)$ ibu memiliki pendidikan setara SMA atau lebih, 19,4\% memiliki pendidikan setara SMP, dan sisanya memiliki pendidikan setara SD. Berdasarkan tingkat paritas, median paritas pada kelompok MPASI buatan pabrik ( $\mathrm{n}=18$, rentang $1-5)$ adalah 1,5 , sedangkan pada kelompok MPASI buatan rumahan memiliki median $2(\mathrm{n}=18$, rentang 1-4). Berdasarkan cara lahir, 31 (86,1\%) bayi lahir secara normal dan 5 bayi lainnya lahir melalui operasi caesar. Dua puluh empat $(66,7 \%)$ bayi lahir ditolong bidan. Status gizi normal

Tabel 1. Karakteristik subjek pada kedua kelompok penelitian

\begin{tabular}{|c|c|c|}
\hline \multirow[b]{2}{*}{ Karakteristik } & \multicolumn{2}{|c|}{ MPASI } \\
\hline & $\begin{array}{l}\text { Buatan pabrik } \\
\quad(\mathrm{n}=18)\end{array}$ & $\begin{array}{l}\text { Buatan rumahan } \\
\quad(\mathrm{n}=18)\end{array}$ \\
\hline \multicolumn{3}{|l|}{ Jenis kelamin } \\
\hline Laki-laki & 5 & 11 \\
\hline Perempuan & 13 & 7 \\
\hline \multicolumn{3}{|l|}{ Pekerjaan ibu } \\
\hline Bekerja & 7 & 2 \\
\hline Tidak bekerja/IRT & 11 & 16 \\
\hline \multicolumn{3}{|l|}{ Pendidikan ibu } \\
\hline SD & 1 & 1 \\
\hline SMP & 2 & 5 \\
\hline$\geq \mathrm{SMA}$ & 15 & 12 \\
\hline \multicolumn{3}{|l|}{ Paritas } \\
\hline Median & 1,5 & 2 \\
\hline Rentang & $1-5$ & $1-4$ \\
\hline \multicolumn{3}{|l|}{ Cara lahir } \\
\hline Normal & 15 & 16 \\
\hline Sectio Caesarea & 3 & 2 \\
\hline \multicolumn{3}{|l|}{ Penolong persalinan } \\
\hline Bidan & 12 & 12 \\
\hline Dokter & 6 & 6 \\
\hline \multicolumn{3}{|l|}{ Status gizi } \\
\hline Normal & 17 & 17 \\
\hline Malnutrisi sedang & 1 & 0 \\
\hline Overweight & 0 & 1 \\
\hline \multicolumn{3}{|l|}{ ASI eksklusif } \\
\hline Ya & 11 & 15 \\
\hline Tidak & 7 & 3 \\
\hline
\end{tabular}


ditemukan pada $94,4 \%$ bayi $(\mathrm{n}=34)$. Dari keseluruhan bayi, $72,2 \%(\mathrm{n}=26)$ memiliki riwayat ASI eksklusif.

Pada Tabel 2 tertera perbedaan kadar $\mathrm{Hb}$ pada kelompok MPASI buatan pabrik dibandingkan buatan rumahan, didapatkan nilai median kadar $\mathrm{Hb}$ pada kelompok MPASI buatan pabrik lebih tinggi dibandingkan kelompok MPASI buatan rumahan dan terdapat perbedaan yang bermakna $(\mathrm{p}=0,030)$.

Perbandingan konsumsi jenis makanan pendamping rumahan berdasarkan kadar $\mathrm{Hb}$ tertera pada Tabel 3. Pada Tabel 3 tertera tidak terdapat perbedaan bermakna dari konsumsi jenis makanan pendamping rumahan berdasarkan kadar $\mathrm{Hb}$ (semua $\mathrm{p}>0,05$ ).

Perbandingan jenis asupan nutrisi makanan pendamping rumahan berdasarkan kadar Hb tertera pada Tabel 4. Pada Tabel 4 tertera perbedaan bermakna pada jenis asupan nutrisi makanan pendamping rumahan berdasarkan kadar $\mathrm{Hb}$ pada kelompok jenis asupan nutrisi lemak $(\mathrm{p}<0,048)$, tetapi tidak ditemukan perbedaan bermakna pada kelompok jenis asupan nutrisi lainnya.

\section{Pembahasan}

Anemia secara global disebabkan oleh defisiensi besi. ${ }^{1}$ Anak merupakan kelompok yang paling berisiko, prevalensi di Indonesia sebesar 31,4-54,5\% dari total penduduk pada tahun 2004 dan 2013. ${ }^{1,3}$ Selain dipengaruhi oleh asupan zat mikronutrien, kadar $\mathrm{Hb}$

Tabel 2. Perbandingan kadar $\mathrm{Hb}$ pada kedua kelompok penelitian

\begin{tabular}{lccc}
\hline & \multicolumn{2}{c}{ MPASI } & \multirow{2}{*}{ Nilai $\left.\mathrm{p}^{*}\right)$} \\
\cline { 2 - 3 } & $\begin{array}{c}\text { Buatan pabrik } \\
(\mathrm{n}=18)\end{array}$ & $\begin{array}{c}\text { Buatan rumahan } \\
(\mathrm{n}=18)\end{array}$ & 0,030 \\
\hline Rata-rata $(\mathrm{SD})$ & $11,48(0,85)$ & $10,82(1,20)$ & \\
Median & 11,4 & 10,75 & \\
Rentang & $10,5-13,0$ & $8,6-14,2$ & \\
\hline
\end{tabular}

Keterangan: *) Uji Mann-Whitney (uji satu pihak)

Tabel 3. Perbandingan konsumsi jenis makanan pendamping rumahan berdasarkan kadar $\mathrm{Hb}$

\begin{tabular}{lccc}
\hline \multirow{2}{*}{ Konsumsi jenis makanan (g/hari) } & \multicolumn{2}{c}{ Kadar Hb } & \multirow{2}{*}{ Nilai $\mathrm{p}^{*}$} \\
\cline { 2 - 3 } & $\begin{array}{c}\mathrm{Hb}>11 \mathrm{~g} / \mathrm{dl} \\
(\mathrm{n}=6)\end{array}$ & $\begin{array}{c}\mathrm{Hb}<11 \mathrm{~g} / \mathrm{dl} \\
(\mathrm{n}=12)\end{array}$ & 0,083 \\
\hline Ayam & $40(0-210)^{* *}$ & $0(0-90)$ & 0,553 \\
Hati ayam & $0(0-30)$ & $0(0-60)$ & 0,616 \\
Daging & $0(0-10)$ & 0 & 0,616 \\
Ikan & $10(0-90)$ & $0(0-40)$ & 0,335 \\
Telur & $0(0-110)$ & $30(0-770)$ & 0,964 \\
Tahu & $92,5(55-440)$ & $140(0-385)$ & 0,553 \\
Tempe & $27,5(0-200)$ & $0(0-175)$ & 0,892 \\
Bayam & $7,5(0-40)$ & $5(0-315)$ & 0,616 \\
Buncis & 0 & $0(0-40)$ & 0,892 \\
Brokoli & $0(0-60)$ & $0(0-40)$ & 0,291 \\
Jeruk & 0 & $0(0-110)$ & 0,750 \\
Pepaya & $50(0-200)$ & $75(0-700)$ & 0,616 \\
Pir & 0 & $0(0-100)$ & 0,662 \\
Pisang & $125(0-350)$ & $112,5(0-350)$ & 0,820 \\
Apel & $0(0-30)$ & $0(0-120)$ & 0,964 \\
Tomat & $0(0-40)$ & $0(0-30)$ & 0,964 \\
Wortel & $25(0-60)$ & $30(0-210)$ & 0,291 \\
Buah naga & 0 & $0(0-100)$ & \\
\hline Ketergannn
\end{tabular}

Keterangan: ${ }^{*}$ ) Uji Mann-Whitney; $\left.{ }^{* *}\right)$ Nilai median dan rentang. 
Hani Hilda Kartika dkk: Perbandingan kadar hemoglobin pada bayi yang diberikan MPASI buatan pabrik dengan buatan rumahan

Tabel 4. Perbandingan asupan nutrisi makanan pendamping rumahan berdasarkan kadar $\mathrm{Hb}$

\begin{tabular}{lccc}
\hline \multirow{2}{*}{ Asupan nutrisi } & \multicolumn{2}{c}{ Kadar $\mathrm{Hb}$} & \multirow{2}{*}{ Nilai $\mathrm{p}^{*}$} \\
\cline { 2 - 3 } & $\mathrm{Hb}>11 \mathrm{~g} / \mathrm{dl}$ & $\mathrm{Hb}<11 \mathrm{~g} / \mathrm{dl}$ \\
$(\mathrm{n}=6)$ & $522,0(12)$ & 0,143 \\
\hline Energi & $\left.643,2(209,8)^{* *}\right)$ & $76,8(23,8)$ & 0,391 \\
Karbohidrat & $90,0(40,4)$ & $16,5(5,8)$ & 0,424 \\
Protein & $19,2(8,3)$ & $17,3(4,2)$ & 0,048 \\
Lemak & $23,2(7,6)$ & $4,4(1,8)$ & 0,191 \\
Besi & $6,4(4,5)$ & $2,14(0,82)$ & 0,089 \\
Zinc & $3,19(1,69)$ & $29,59(12,73-95,37)$ & 0,616 \\
Vitamin C & $34,75(10,97-55,12)$ & $72,3(30,1)$ & 0,365 \\
Folat & $59,7(18,2)$ & & \\
\hline
\end{tabular}

Keterangan: *) Uji t-tidak berpasangan; kecuali untuk vitamin C dengan uji Mann-Whitney.

$\left.{ }^{* *}\right)$ nilai rata-rata dan simpang baku; kecuali untuk vitamin $\mathrm{C}$ nilai median dan rentang.

dipengaruhi juga oleh beberapa faktor, antara lain, kehamilan yang diinginkan, paritas, usia gestasi, jenis kelamin, waktu pemotongan tali pusat, pemberian ASI, status anemia ibu, tingkat pendidikan ibu dan tingkat kesejahteraan. ${ }^{12,14,15}$ Pertumbuhan dan perkembangan anak berlangsung semakin cepat saat menginjak usia di atas 6 bulan. Pemberian ASI saja tidak dapat memenuhi kebutuhan nutrisi yang diperlukan maka dari itu makanan pendamping ASI (MPASI) mulai diberikan pada usia 6 bulan untuk memenuhi asupan nutrisi agar pertumbuhan dan perkembangan dapat berlangsung optimal. ${ }^{9-11,17}$ Pemberian MPASI harus secara tepat, adekuat, dan aman. Pemberian MPASI dapat berupa buatan rumahan ataupun komersil buatan pabrik. Kebutuhan kalori anak usia 6-8 bulan sebesar $200 \mathrm{kkal} /$ hari bagi yang mendapatkan ASI dan $600 \mathrm{kkal} /$ hari bagi yang tidak mendapatkan ASI dengan komposisi protein 9,1 gram/hari atau 20\% dan lemak $30 \%$ dari total asupan kalori. Untuk kebutuhan harian mikronutrien diharapkan dapat tercukupi 70\%-80\% dari makanan pendamping. ${ }^{10-11}$

Di negara berkembang, MPASI berfortifikasi buatan pabrik jarang diberikan karena pertimbangan ekonomis. Ibu lebih sering membuat MPASI buatan rumahan dengan resep tradisional dan seringkali zat gizi yang diberikan tidak seimbang dan tidak dapat memenuhi kebutuhan zat mikronutrien. ${ }^{11}$

Fortifikasi makanan pertamakali dicanangkan oleh WHO pada tahun 1992 dan secara universal direkomendasikan bagi negara-negara yang dianggap berisiko tinggi terjadinya defisiensi zat besi. ${ }^{12} \mathrm{Di}$ Indonesia, fortifikasi makanan yang mengandung zat besi ditetapkan dalam surat Keputusan Menteri
Kesehatan Republik Indonesia Nomor 1452/ MENKES/SK/X/2003 tentang fortifikasi tepung terigu. Keputusan Menkes yang menetapkan bahwa tepung terigu yang diproduksi, diimpor atau diedarkan di Indonesia harus ditambahkan fortifikan sehingga mengandung besi minimal 50 persenpermili (ppm), seng minimal $30 \mathrm{ppm}$, vitamin B1 minimal 2,5 $\mathrm{ppm}$, vitamin B2 minimal $4 \mathrm{ppm}$, dan asam folat minimal 2 ppm. ${ }^{17}$ Sementara itu, kebijakan fortifikasi zat gizi mikro termasuk zat besi anak adalah dengan pemberian taburia.

Indonesia mulai mengembangkan formulai zat gizi mikro pada tahun 2006 dan ditetapkan melalui Peraturan Menteri Kesehatan Republik Indonesia Nomor 2409/MENKES/PER/XII/2011 tentang standar bubuk tabur gizi. ${ }^{18}$ Fortifikasi besi di negaranegara yang memiliki pendapatan perkapita rendah hingga menengah merupakan komponen intervensi yang penting untuk mencegah defisiensi mikronutrien dan anemia, meningkatkan pola makan bayi dan anak. ${ }^{12,19-20}$

Pada penelitian kami, usia gestasi, paritas, jenis kelamin, status gizi, tingkat pendidikan ibu dan pemberian ASI tidak bermakna secara statistik dengan kadar $\mathrm{Hb}$ pada kedua kelompok. Hal tersebut berbeda dengan hasil penelitian Patron ${ }^{12}$ dan Lestari ${ }^{13}$ yang melaporkan bahwa pendidikan ibu pada tingkat sekolah menengah, tingkat kesejahteraan, jenis kelamin anak memiliki korelasi positif terhadap kadar $\mathrm{Hb}$.

Patron ${ }^{12}$ melaporkan pada studinya di India bahwa pemberian makanan pendamping sereal yang berfortifikasi memiliki korelasi positif terhadap kadar $\mathrm{Hb}$. Sementara jenis makanan lain, seperti roti, gandum, 
produk unggas, kacang-kacangan memiliki korelasi negatif terhadap kadar $\mathrm{Hb}$ anak usia 6-23 bulan. Lestari ${ }^{13}$ pada penelitiannya di Solo melaporkan bahwa anemia terjadi pada 35\% subjek. Sebesar 97\% subjek diberikan makanan pendamping yang berbahan dasar nasi, $90 \%$ subjek tidak memiliki asupan protein hewani yang adekuat dan asupan buah jeruk yang mengandung vitamin $\mathrm{C}$ kurang. Lestari juga menyimpulkan bahwa status gizi, rendahnya asupan jenis makanan berupa buah jeruk dan tidak diberikannya sereal atau formula yang berfortifikasi besi berhubungan dengan anemia. Pada penelitian kami didapatkan rata-rata kadar $\mathrm{Hb}$ bayi yang diberikan MPASI buatan pabrik $(11,48 \mathrm{~g} / \mathrm{dL})$ lebih tinggi dibandingkan dengan buatan rumahan $(10,75$ $\mathrm{g} / \mathrm{dL})$. Jenis makanan pendamping yang diberikan dan jumlah asupan mikronutrien akan memengaruhi kadar $\mathrm{Hb}^{20}{ }^{20}$ Duabelas $(66,7 \%)$ bayi pada kelompok MPASI buatan rumah memiliki kadar $\mathrm{Hb}$ yang rendah di bawah $11 \mathrm{~g} / \mathrm{dL}$. Asupan harian makanan jenis ayam dan bayam yang mengandung besi tinggi pada bayi kelompok MPASI buatan rumahan memiliki kadar $\mathrm{Hb}$ di atas $11 \mathrm{~g} /$ dL lebih tinggi dibandingkan dengan bayi yang memiliki kadar $\mathrm{Hb}$ di bawah $11 \mathrm{~g} / \mathrm{dL}$. Asupan harian buah-buahan yang mengandung vitamin $\mathrm{C}$, seperti pepaya dan wortel, lebih tinggi pada bayi yang memiliki kadar $\mathrm{Hb}$ di atas $11 \mathrm{~g} / \mathrm{dL}$ dibandingkan dengan bayi yang memiliki kadar $\mathrm{Hb}$ di bawah $11 \mathrm{~g} / \mathrm{dL}$.

Studi lain oleh Hilbig $\mathrm{dkk}^{21}$ membandingkan komposisi MPASI buatan rumahan dengan buatan pabrik. Dalam studi ini, peneliti membagi mengklasifikasikan MPASI buatan pabrik menjadi beberapa jenis. Hasil studi tersebut melaporkan bahwa asupan lemak dan besi yang dikonsumsi bayi usia 6-12 bulan dari makanan pendamping buatan rumah lebih tinggi dibandingkan dengan makanan pendamping buatan pabrik yang mengandung protein hewani yang dikombinasikan dengan sayur, kentang ataupun sereal tanpa adanya kandungan susu dan jenis makanan lain yang mengandung sereal, sayur, dan buah.

Osendarp ${ }^{20}$ melakukan kajian sistematis mengenai kecukupan gizi makanan pendamping yang dibuat secara lokal dan tradisional pada bayi berusia 6-23 bulan di negara berkembang. Dari kajian tersebut didapatkan bahwa asupan kalsium, besi, dan zinc dari makanan pendamping yang diberikan tidak mencukupi kebutuhan nutrisi yang seharusnya. Osendarp merekomendasikan bahwa hal tersebut dapat dioptimalisasi, tetapi memerlukan dukungan dari pembuat kebijakan untuk menentukan strategi yang efektif secara pembiayaan. Pada penelitian kami, asupan lemak, besi, zinc, dan vitamin $\mathrm{C}$ lebih tinggi pada kelompok bayi yang diberikan MPASI buatan rumahan, dengan kadar $\mathrm{Hb}$ lebih dari $11 \mathrm{~g} / \mathrm{dL}$, tetapi asupan folat lebih tinggi pada bayi dengan kadar $\mathrm{Hb}$ kurang dari $11 \mathrm{~g} / \mathrm{dL}$, secara statistik hanya jenis asupan lemak yang bermakna secara signifikan terhadap kadar $\mathrm{Hb}$.

Terdapat beberapa keterbatasan dalam penelitian kami, yaitu waktu pemotongan tali pusat dan sebagian besar kadar $\mathrm{Hb}$ ibu selama hamil yang dapat memengaruhi kadar $\mathrm{Hb}$ pada bayi tidak diketahui.

\section{Kesimpulan}

Kadar hemoglobin pada bayi yang mendapatkan MPASI buatan pabrik lebih tinggi dibandingkan bayi yang mendapatkan MPASI buatan rumahan. Pemberian MPASI buatan pabrik dapat direkomendasikan sebagai salah satu upaya pencegahan anemia defisiensi besi. Diharapkan pada penelitian selanjutya dilakukan analisis secara kohort dan menelaah status anemia ibu dan waktu pemotongan tali pusat untuk menyingkirkan compounding factor.

\section{Daftar pustaka}

1. WHO. Iron deficiency anemia assessment, prevention, and control a guide for programme managers. Geneva: WHO; 2001.h.1-132.

2. Kemenkes. Riset kesehatan dasar. Jakarta: Kemenkes 2013.h.1306.

3. Kassebaum NJ, Jasrasaria R, Naghavi M, Wulf SK, Johns N. A systematic analysis of global anemia burden from 1990 to 2010. Blood 2014;123:615-25.

4. Barkley JS, Kendrick KL, Codling K, Muslimtun S, Pachón $\mathrm{H}$. Anaemia prevalence over time in Indonesia: estimates from the 1997, 2000, and 2008 Indonesia Family Life Surveys. Asia Pac J Clin Nutr 2015;24:452-5.

5. Domello M, Hernell O. Iron-deficiency anaemia during the first two years of life. Scandinavian J Nutr 2002;46:20-30.

6. Maguire JL, Salehi L, Birken C, dkk. Association between total duration of breastfeeding and iron deficiency. Pediatrics 2013;131:1530.

7. Guyton A, Hall JE. Textbook of medical physiology in red blood cells, anemia and blood clotting. Edisi ke-13. London: Elsevier; 2015.h.419-28. 
Hani Hilda Kartika dkk: Perbandingan kadar hemoglobin pada bayi yang diberikan MPASI buatan pabrik dengan buatan rumahan

8. WHO. Appropriate complementary feeding. Diakses pada tanggal 1 April 2018. Didapat dari: www.who.int.

9. Asosiasi Dietesien Indonesia, Persatuan Ahli Gizi Indonesia, Ikatan Dokter Anak Indonesia . Penuntun Diet Anak dalam Makanan Pendamping ASI. Edisi ke-2. Jakarta; 2009.h.15-24.

10. Abeshu MA, Lelisa A, Geleta B. Complementary feeding: Review of reccomendations, feeding practices and adequacy of homemade complementary food preparations in developing countries-lesson from Etiophia. Frontiers in nutrition 2016;3:41.

11. Fontaine O. Conclusions and recommendations of the WHO consultation on prevention and control of iron deficiency in infants and young children in malaria-endemic areas. Food and Nutr Bul 2007:28:621-31.

12. Patron AP, Hutton ZV, Garg P, Rao S, Eldridge AL, Detzel P. The association between complementary foods and hemoglobin concentration in Indian infant. J Hun Nutr Food Sci 2017;5:1105.

13. Lestari ED, Moelya AG, Rohana E, Wiboworini B. Relation of complementary food and anemia in urban underpriviliged children in Surakarta. Pediatrica Indones 2007;47:196-201.

14. Ashis KC, Rana Nisha RN, Alqvist M, Ranneberg LJ, Subedi $\mathrm{K}$, Anderson O. Effects of delayed umbilical cord clamping on anemia in infants at 8 and 12 months a randomized clinical trial. JAMA Pediatr 2017;171:264-70.
15. Giyantini H, Indjradinata P, Garna H. Perbedaan status besi bayi normal yang mendapat air susu ibu eksklusif dengan susu formula standar. Sari Pediatri 2013;15:127-32.

16. Diana A, Mallard SR, Haszard JJ, dkk. Consumption of fortified infant foods reduces dietary diversity but has a positive effect on subsequent growth in infants from Sumedang district, Indonesia. Plos one 2017:1-17.

17. Kemenkes. Keputusan menteri kesehatan tentang fortifikasi tepung terigu NO 1452/MENKES/SK/X/2003. Jakarta: Menteri Kesehatan Republik Indonesia; 2003:1-3.

18. Kemenkes. Standar bubuk tabur gizi NO 2409/MENKES/ PER/XII/2011. Jakarta: Kementerian Kesehatan Republik Indonesia; 2011:1-8.

19. Paganini $D$, Uyoga MMA, Zimmermann MB. Iron fortification of foods for infants and children in low income countries : Effects on the gut microbiome, gut inflamation and diarrhea. Nutrients 201:8:494-504.

20. Osendarp SJM, Broersen B, van Liere MK, dkk. Complementary feeding diets made of local foods can be optimized, but additional interventions will be needed to meet iron and zinc requirements in 6- to 23-month-old children in low- and middle-income countries. Food Nutr Bull 2016;37:544-70.

21. Hilbig A, Foterek K, Kersting M, Alexy U. Home-made and commercial complementary food in German infants: results of the DONALD study. J Hum Nutr Diet 2015;28:613-22. 